\title{
A DÉL-DUNÁNTÚL NEMZETKÖZI VERSENYKÉPESSÉGÉNEK ELŐFELTÉTELE, A TECHNOLÓGIAI MEGÚJULÁS
}

\author{
(Prerequisite of the International Competitiveness \\ of South Transdanubia, Technological Renewal)
}

\section{HORVÁTH GYULA}

\section{Regionális fejlôdés és a technológiai megújulás}

Egy régió gazdasági fejlödésében - a történeti korok sajátosságaihoz igazodva - különbözõ tényezök játszanak meghatározó szerepet. A Dél-Dunántúl második világháború utáni átalakulásában elsôdleges hajtóereje az iparosításnak volt. A dezindusztrializáció tipikus periférikus modelljét követve a térség szerkezeti átalakítása külsố forrásokból, régión kivuüli (központi és vállalati) döntések nyomán zajlott. Még a térség belsõ adottságaihoz leginkább kapcsolódó élelmiszergazdaság fejlesztése is ezen a pályán haladt. A hullámszerũen lejátszódó iparosításra elốször a nagyvárosokba a budapesti, majd késôbb a nagyobb falvakba a régió városi feldolgozóiparának kitelepítései voltak jellemzóek.

A centrumokból kiinduló hatások lényegében hasonló következményekkel jártak, mint a nyugat- és dél-európai regionális fejlôdésben. A Dél-Dunántúlon - a gazdaság-és társadalomirányítás akkor uralkodó rendje miatt - nem is lehettek olyan erôk, amelyek megakadályozhatták volna, hogy a központi régió ipari tevékenységét átszervezvén, az új termék- és technológiai innováció számára megtisztítván tevékenységi profilját, felhagyott - életciklusok végsõ szakaszában lévố - termékeinek gyártását a régióba telepítse. A budapesti ipar dekoncentrációjának másik - a Dél-Dunántúl iparosítására is ható - vonulatában a vertikálisan szervezett innovatív nagyvállalatok korszerü technológiát telepítettek Pécsre (Mechanikai Laboratórium), Nagykanizsára (Egyesült Izzó), Kaposvárra (Egyesült Izzó, Finommechanikai Vállalat), ezek azonban csupán részegységek előállítására specializálódtak, illetôleg a termékfejlesztés és -értékesítés stratégiai döntési posztjai a fôvárosban maradtak. Ritka kivételnek számított, ha egy nagyvállalat több megyébe telepített gyáregységei termelési kapcsolatot létesítettek egymással. A Dél-Dunántúl belsô gazdasági kohéziója gyenge volt. A dél-dunántúli ipar ágazati kapcsolatait elemzô korábbi vizsgálatunk (Horváth Gy. 1981) azt mutatta, hogy az elốállított félkész- és késztermékeknek csupán 12\%-a maradt a régióban, a többi továbbfel- 
dolgozásra elhagyta azt. A belsố regionális erôforrásokból kifejlôdött vállalatok és ipari szövetkezetek - amennyiben piacképes termékeket állítottak elố - innovációs kapcsolataikban elsõsorban a centrumtól függtek (a hitelezés, a külkereskedelmi értékesítés, a technológiai és piaci információk megszerzése csak budapesti szervezeteken keresztül volt lehetséges).

A dél-dunántúli megyék és települések a 80-as évtized közepéig passzív szerepre kényszerültek ebben a folyamatban, s csak ezt követõen fogalmazódhattak meg elképzelések a szerkezetátalakítás irányaira. Ekkor azonban már sorra építették le a leányvállalatokat, az ipari kibocsátás mérséklôdött, az exportteljesítmények romlottak. A gazdasági válság tehát megakadályozta, hogy legalább az ún. perifériahasznosítási modell bizonyos elemeit alkalmazni lehessen. A korábbi fejlôdési pálya olyannyira mély nyomokat hagyott a régió politikai és tanácsi döntéshozóiban, hogy a kitörési pontokat továbbra is csupán a hagyományos, a külsõ erốforrások mobilizálásában látták (a privatizációt, vegyesvállalat-alapítást tekintették a szerkezetváltozás lényegének).

Felfogásunk szerint a gazdaság szerkezeti átalakulásának, ágazati átrendezõdésének, a versenyképes struktúra kiépülésének kulcsa - ezzel szemben - a Dél-Dunántúl innovációs potenciáljának az erõsítésében, a technikai és a technológiai megújulásban, a termék- és a termelési innováció szolgáltatási hátterének a megteremtésében van.

A nyugat-európai regionális fejlôdésben mind a technológiaváltozásnak, mind pedig a fejletlen perifériák technológiai színvonalának, a termelési, üzleti és információs háttérágazatok fejlesztésének meghatározó jelentõsége volt az utóbbi másfél évtizedben. Ezek a feladatok egyrészt prioritást kaptak a nemzeti regionális programokban, másrészt az Európai Közösség is a legfontosabb, kohéziót erôsítô célprogramjává nyilvánította az elmaradott és depressziós térségek innovációs potenciáljának fejlesztését.

Az Európai Regionális Fejlesztési Alap két fontos programja a technológiai változás elôkészitésére és finanszirrozására jött létre. A STRIDE-program (Science and Technology for Regional Innovations and Development in Europe) a regionális $\mathrm{K}+\mathrm{F}$ fejlesztését, a SPRINT-program (European Community Strategic Programme for Innovation and Technology Transfer) pedig a technológiai transzfer-rendszerek és hálózatok kialakítását támogatja.

A STRIDE alapfilozófiája arra épül, hogy:

- az elmaradott perifériákon a fenntartható fejlôdés a technológiai képességek gyökeres megváltoztatásával képzelhetô csak el;

- a regionális támogatások korábbi formái nem mérsékelték a centrum- és a periférikus térségek közötti gazdasági különbségeket. Az egymástól elszigetelt programok helyett olyan koherens projektekre van szükség, amelyek a regionális alulfejlettség kiváltó okait szüntetik meg;

- a technológiai rés a különbözõ fejlettségũ térségek között a gazdasági és életszínvonalbeli differenciáknál sokkal nagyobb;

- a szegényebb régiókban azokat a képességeket kell erôteljesen fejleszteni, amelyek a függôség és kiszolgáltatottság jelentõs mérséklôdését eredményezhetik. 
A SPRINT-program az innovációbarát gazdasági kömyezet megteremtését, a technológiai közvetítô hálózatok regionális kiépítését célozta meg az alábbi stratégiai irányvonalak mentén:

- az innovációtámogatás európai hálózatának kiépítése;

- az új technológiák és mũszaki megoldások elterjesztése a közösség vállalatai között, a vállalatok a kutató és technológiai szervezetek és a beruházók nemzetközi együttmúködését lehetôvé téve;

- az innovációs folyamat fontosságát bizonyító eredmények széles körũ regionális terítése, információs központok megszervezése.

A program prioritásai a következők:

- a kisvállalkozások innovációs képességének erôsítése,

- a hagyományos ágazatok technikafelszívó képességének javitása,

- a technológiai kapcsolatok megteremtése a fejlett és a fejletlen régiók között,

- az innovációs folyamat részelemeinek (minõség, design, értékelemzés, szabványosítás, szabadalom- és találmányhasznosítás) erõsítése.

Az innovációs politikájukat már korábban decentralizált országok (Dánia, Hollandia, Olaszország, Németország, Franciaország) tapasztalatai (és a decentralizációt megalapozó vizsgálatok) azt bizonyították, hogy a $\mathrm{K}+\mathrm{F}$ tevékenység intenzitása, a kisvállalkozások fejlődőképessége és az exportképesség között szoros a korreláció.

Amennyiben a Dél-Dunántúl távlati gazdasági fejlôdésében a nemzetközi versenyképesség erôsítését à priori feltételnek tekintjük, a technológiai és a szervezeti innovációt stratégiai elemként kell kezelnünk, s a különbözõ részterületekre fejlesztési programokat kell kidolgozni.

A kiinduló feltételek ugyanis mind a négy megyében igen kedvezõtlenek. Nemcsak az Alföld és Észak-Magyarország, hanem Dél-Dunántúl is félperiférikus állapotokat tükröz. Az innovációs potenciál bármely elemét nézzük, Budapest dominanciája a meghatározó (de az Észak-Dunántúl is a többi nagyrégió fajlagos mutatóinak kb. a kétszeresét produkálja). Ebbôl az is következik, hogy a magyar regionális politikának erổteljes figyelmet kell forditania a $\mathrm{K}+\mathrm{F}$ tevékenység decentralizálására, befolyását latba kell vetnie ahhoz, hogy a fiskális, a monetáris, az ipar-és a kereskedelempolitika tekintettel legyen arra, hogy e régiók válságmenedzselése ugyan elképzelhetố a technológiai-kutatási kapacitások nagyarányú fejlesztése nélkül, a fellendülés azonban nem. A STRIDEprogram alapcélkitüzéseit be kell építeni a magyar regionális politika célrendszerébe.

Mi jellemzi a négy dél-dunántúli megye innovációs kapacitását? A helyzetértékelés még csupán néhány alapinformációra épülhet, ugyanis a $K+F$ szektorról és az innováció más szféráiról szekunder területi információk csak részlegesen állnak rendelkezésre. $\mathrm{Az}$ adatok vagy régi keletūek (a $\mathrm{K}+\mathrm{F}$ évkönyv 1986-ban közölt utoljára területi adatokat) vagy pedig teljes mértékben hiányoznak (pl. nincs adat a találmányok, újítások, szabadalmak, a csúcstechnológiai eszközök területi megoszlásáról). Elemzésünk e szakaszában tehát csak tendenciákat és hipotéziseket jelezhetünk. Az innovációs potenciál teljes körũ elemzése a részletes empirikus adatfelvétel és -feldolgozás után végezhetô el. 
Ez a felmérés átfogóbb képet adhat részben az adottságokról, részben pedig a gazdasági és a $\mathrm{K}+\mathrm{F}$ szektor fejlesztési elképzeléseirốl, attitũdjeirôl, a Dél-Dunántúlon gyártott termékek és az ott nyújtott szolgáltatások színvonaláról, versenyképességéról. A tervezett adatfelvétel eredményei elé azért tekintünk bizakodóan, mert egy más típusú - a baranyai kisvállalkozók körében végzett - felmérésünk (Kraftné Somogyi G. 1993) eredményei is hasznos információkat szolgáltattak hipotéziseink alátámasztására, ugyanis az derült ki, hogy:

- hiányzik a technológiai szakképzettség, az új technológiák iránti tudatos érdeklôdés;

- az elốálított termékek mũszaki szinvonala alacsony, továbbá elenyészố a minôségi és formatervezett termékek aránya;

- a vállalkozások kizárólag hazai és kelet-európai piacra termelnek;

- kooperációs képességük rendkívül gyenge, egyetlen dél-dunántúli nagy- és középvállalattal nem állnak termelési kapcsolatban;

- piaci ismereteik hiányosak, marketing tevékenységet nem folytatnak.

\section{Az innovációs elmaradottság okai a Dél-Dunántúlon}

Egy térség versenyképességét meghatározó innovációs potenciál számtalan tényezô mũködésének és ezek kölcsönhatásainak az eredõje. A legfontosabb innovációs elemeket - vázlatosan - az 1. ábra mutatja.

1. ÁBRA

A technológiai átalakulás hagyományos lineáris modellje

(Traditional linear model of the technological transition)

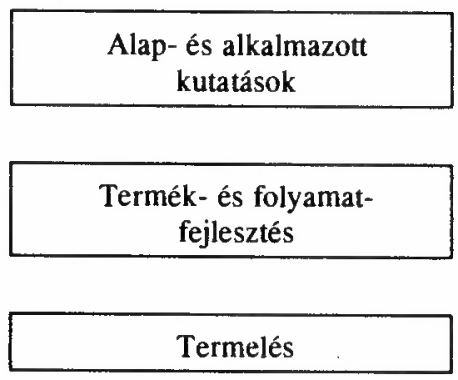

Marketing, üzleti

szolgáltatások, érté-

kesítési rendszerek 
A mũszaki-technológiai képességek helyzetfeltárásához az innovációs lánc tradicionális értelmezése is elegendô, a stratégia kidolgozása során azonban már egy lényegesen átalakított modellel kell majd operálnunk, amelyik alkalmas arra, hogy az egyes elemek közti kapcsolatokat is figyelembe vegye. A technológiaváltás folyamata ugyanis nemcsak az innovációs elemek minöségi átalakulását és mennyiségi fejlôdését jelenti, hanem az egyes elemek egymásrahatását elốsegítö mechanizmusok fejlesztését egyaránt. A korábban is fejlett technológiai rendszerekkel rendelkezõ régiók innovációs kapacitásaikat éppen azért tudták megsokszorozni, mert az innovációk lineáris fejlesztése helyett stratégiájukat a komplexitás megteremtésére, az egyes innovációs alrendszerek egymáshoz kapcsolására alapozták.

\section{A gyenge kutatási-fejlesztési hálózal}

Bár a külsõ szemlélönek gyakran az az érzése, hogy a Dél-Dunántúlon jelentõs kutatási kapacitások vannak, ez a felszínes kép azonban a $\mathrm{K}+\mathrm{F}$ adatok elemzése során módosul, mert igencsak kedvezôtlen állapotok tárulnak elénk. Nem csupán a közeli középeurópai régiók vagy a közös piaci országok átlagos $K+F$ adataival összehasonlítva, hanem a hazai nagyrégiókkal összevetve is szembetünõ a Dél-Dunántúl elmaradottsága.

A 80-as évtized végének adatai szerint az ország $K+F$ foglalkoztatottjainak csupán 3,5\%-a dolgozott a Dél-Dunántúlon, a ráfordításoknak pedig mindössze $1,5 \%$-a került ide (1. táblázat). Az adatok nem tükrözik teljességében a régió kutatási kapacitásait, mert csupán a dél-dunántúli székhelyũ $K+F$ szervezeteket tartalmazzák, nem szerepel az összesítésben pl. a Tejgazdasági Kísérleti Kutatóintézet pécsi osztálya, több kívülrôl irányított agrárkutatóhely és a Mecseki Ércbányászati Vállalat kutatási üzeme sem, illetve az akkori kutatási-fejlesztési statisztika viszonylag magas követelményekhez kötötte a vállalati kutatóhelyi besorolást. Másfelôl viszont a hivatalos statisztika nagyvonalúan járt el, mert a teljes felsổoktatási oktatói létszámot kutató-fejlesztô állománynak minösítette. A számbavételi pontatlanságok ellenére a régió helyzete egyértelmú, az ország nagy tájai közül a leggyengébb $K+F$ kapacitásokkal rendelkezik.

Ennek oka több tényezõre vezethetố vissza:

1) Az ország kutatási kapacitása túlzottan magas - Európában szinte egyedülálló koncentrációt mutat (a fóvárosra és Pest megyére jut a foglalkoztatottak és a ráfordítások háromnegyed része, 2. ábra). A nemzetközi szakmai közvélemény értékelése szerint torz - északi orientációjú - $\mathrm{K}+\mathrm{F}$ szerkezettel rendelkezõ Olaszországban a koncentráció foka 51,4\%, a technológiailag fejletlen Mezzogiorno részesedése 24,1\%.

2) A K+F szektor bázisát jelentõ felsôoktatási intézményrendszer beisõ szerkezetében a kevésbé ráfordításigényes társadalomtudományok dominálnak, a nem felsõoktatási kutatóhelyek is elsôsorban ebbe a tudományágba tartoznak (levéltárak, múzeumok, könyvtárak). 


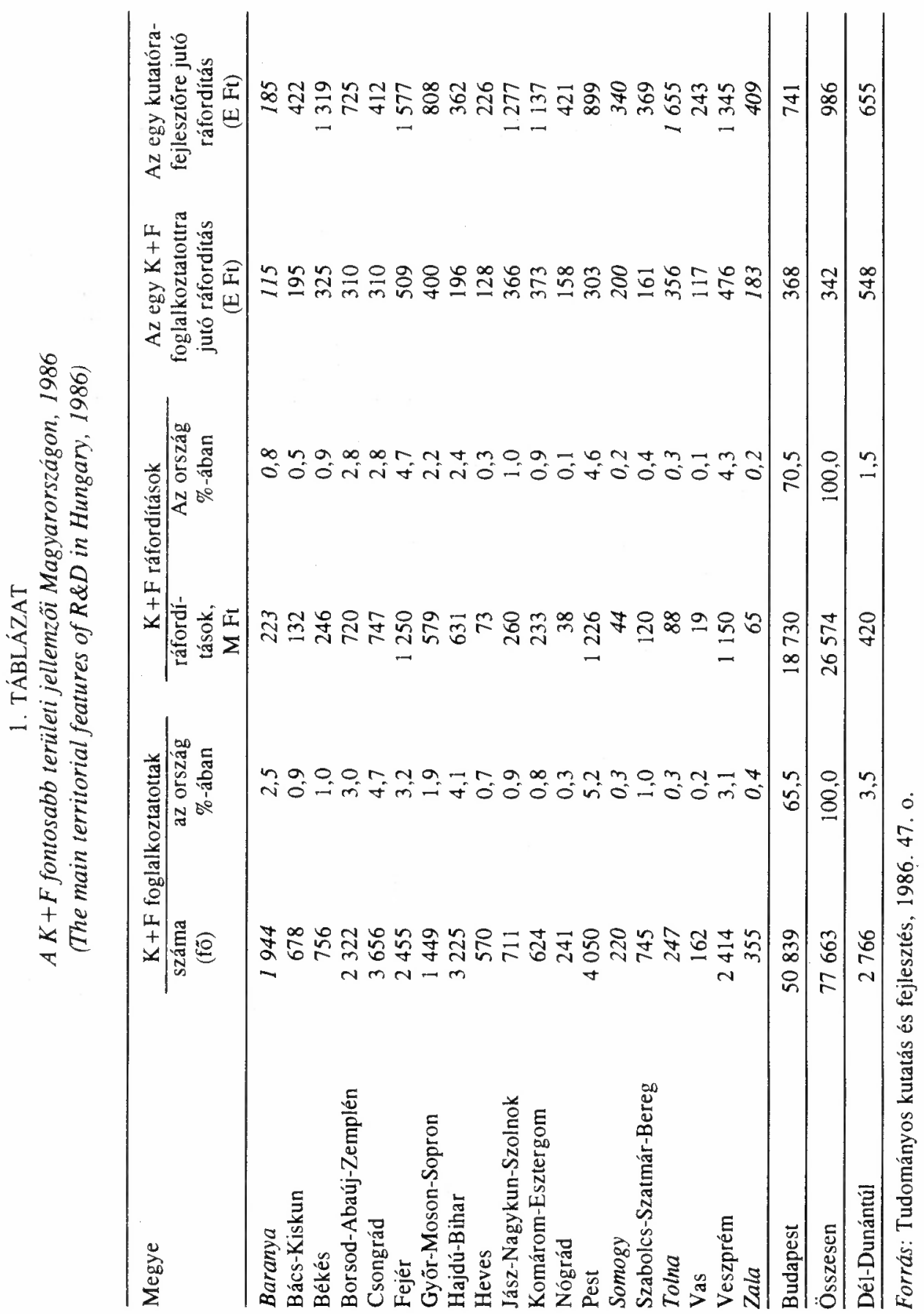


A Dél-Dunántúl nemzetközi versenyképességének elöfeltétele: a technológiai megújulás.

Tér és Társadalom, 8. 1994. 1-2. 37-58. p.

\section{2. ÁBRA}

A kutatási-fejlesztési ráfordítások regionális megoszlása (Regional division of the $R \& D$ expenses)

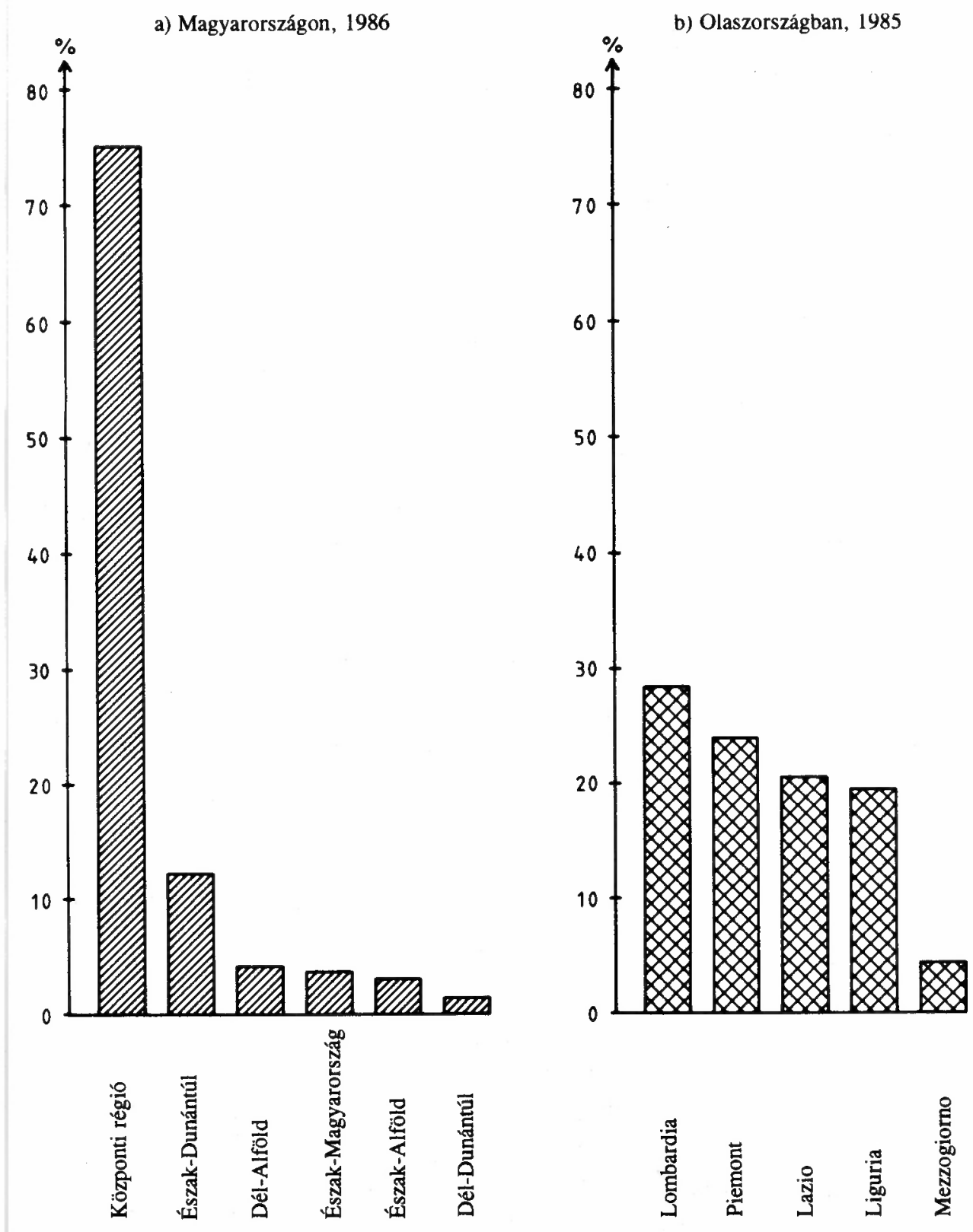

Szerkesztette: Horváth Gyula. 
3) A vállalati $K+F$ helyek száma elenyészõ (a $K+F$ statisztika mindössze nyolc vállalati kutatóhelyet említ a Dél-Dunántúlon).

A félmilliárd forintot sem elérô $K+F$ ráfordítások régión belüli megoszlása egyenetlen, s hasonló megállapítás tehetố a fajlagos ráfordítások tekintetében is. Ez utóbbi mutatóban tapasztalható kedvezõ jelenséget (a dél-dunántúli átlag az országosnak a kétharmada) azonban fenntartással kell fogadnunk, hiszen ez a kiugróan magas Tolna megyei (paksi atomerốmũ!) átlagnak köszönhetố. A többi megye adatai az országos átlag felét sem érik el, Baranya megye egy kutató-fejlesztôre jutó ráfordítása pedig az országos sorrendben az utolsó helyet foglalja el az országos átlag 18,8\%-ával (3. ábra).

Összességében tehát megállapíthatjuk, hogy a Dél-Dunántúl kutatási-fejlesztési kapacitásai gyengék, sem volumenük, sem belsô struktúrájuk nem alkalmas arra, hogy regionális innovációs láncolatot alkossanak, az egyes elemek között tartós kapcsolatok fejlődjenek ki, lokális és regionális technológiaigényes clusterek jöjjenek létre.

\section{Tradicionális vonások a felsöoktatásban}

A felsốoktatás nem csupán a $\mathrm{K}+\mathrm{F}$ szektorban elfoglalt vezetố helye, hanem a technológiailag fejlett termékeket és versenyképes szolgáltatásokat megszervezõ és előállító, valamint az ezek értékesítését végzó szakemberek képzésében elfoglalt meghatározó pozíciója miatt van hatással a belsõ regionális fejlôdésre. A technológiai átalakulás egyik fontos kísérố jelensége, hogy a versenyképes termékeket gyártó iparágak és vállalatok minóségi kritériumok alapján választanak telephelyet. Ezek sorában elôkelố helyen szerepel a felsổoktatás, amelynek tôkevonzó erejét nem csak az általa biztosított munkaerôpiaci elônyök befolyásolják, hanem az ide összpontosuló innovációs kapacitások is. Megfigyelhetô Európa-szerte, hogy míg a nagy technológiai rendszerek fejlödésére elsốsorban az agglomerációs nagyvállalatok kutató-fejlesztô szervezetei voltak meghatározó befolyással, addig a kis- és középvállalkozások technológiai megújulásában, a lokális és regionális technológiai clusterek megszervezôdésében a felsôoktatási intézmények domináltak. A regionális felsõoktatási intézmények motorikus szerepe bizonyítható a közép- és az északkelet-olaszországi ipari körzetek kifejlődésében, a bajor, az északkelet-francia, a holland stb. regionális fejlôdésben (Ciciotti, E. 1993; Bennett, R. J.-Krebs, G. 1991).

Ahhoz azonban, hogy a felsôoktatási hálózat ezt a funkcióját gyakorolni tudja, képes legyen az innovációs rendszer elemeként integráló feladatok ellátására, legalább négy feltételnek kell megfelelnie:

- a kutatást a felsốoktatás egyik alapfunkciójának kell minôsíteni, finanszírozásában erre tekintettel kell lenni, az egyetemek-fôiskolák mũködésében ezt érvényesíteni szükséges;

- az országos technológiapolitikának és a regionális szerveknek megfelelô ösztönzókkel kell támogatniuk a felsôoktatás és a gazdaság szervezett együttmüködését; 


\section{3. ÁBRA}

Az egy kutató-fejlesztôre jutó ráfordítások országos átlagtól

való eltérése megyénként, 1986

(The differences from the national average in the expenses per researcher-developer in the counties, 1986)

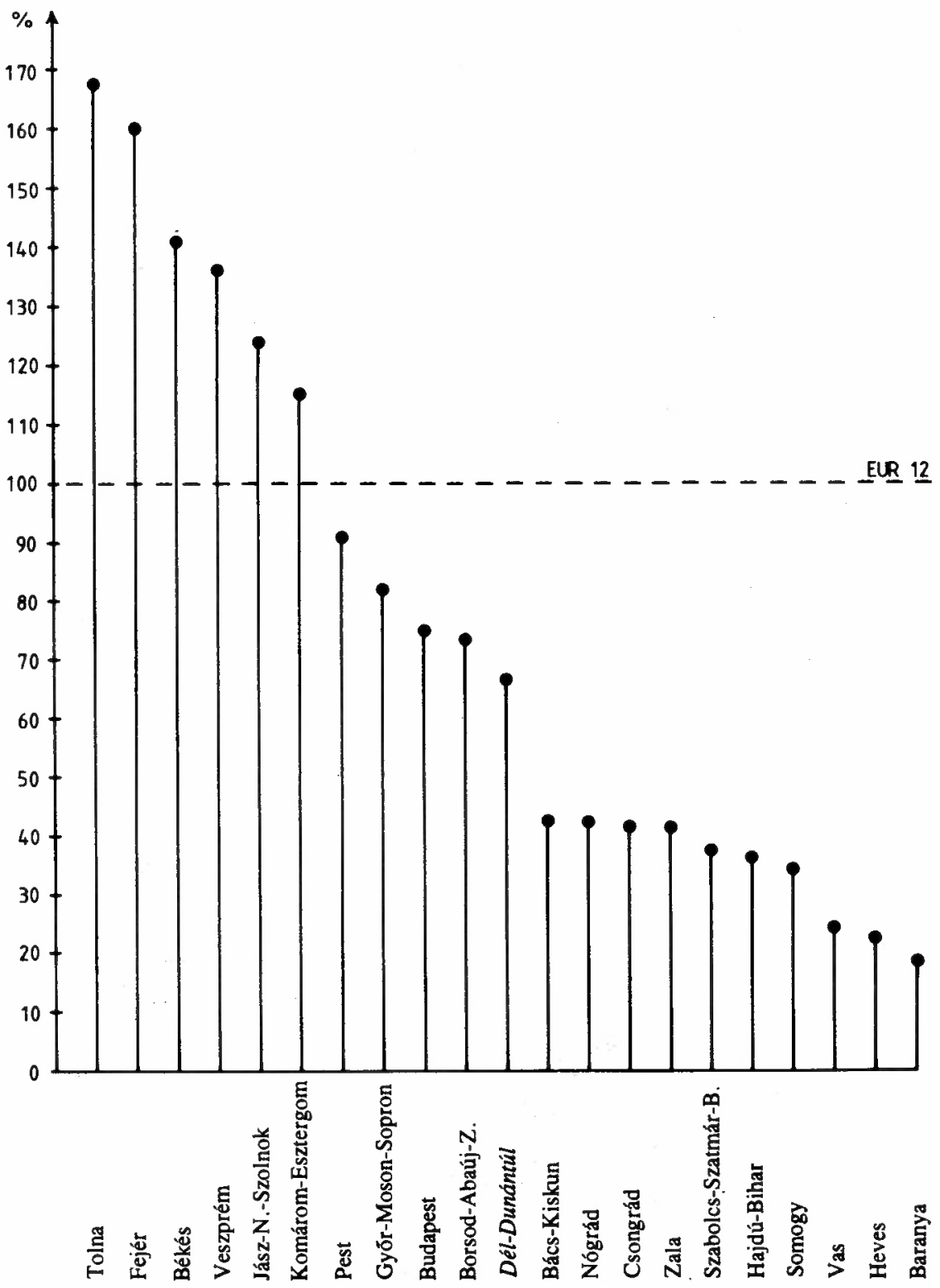


- a felsőoktatás szerkezetének alkalmasnak kell lennie a technológiai és a gazdasági innovációk generálására;

- a felsôoktatásnak területileg decentralizáltnak kell lennie, intézményi méreteinek pedig el kell érnie azt a kritikus tömeget, ami e funkciók gyakorlásához szükséges, illetve ami a centrumrégió intézményeivel esélyegyenlõséget teremt mind a kutatási iorrások megszerzésében, mind pedig a nemzetközi kutatási-fejlesztési munkamegosztásba való bekapcsolódásban.

E tényezõk hazai állapotának értékelése hosszabb tanulmányt igényelne, ehelyütt elegendônek tartjuk csupán arra utalni, hogy:

1) A magyar felsôoktatás lényegében az európai átlagnak megfelelô mértékben részesedik a $\mathrm{K}+\mathrm{F}$ forrásokból (2. táblázat). A K +F szervezetrendszerben tehát nem ennek az elemnek a relatív gyengesége jelenti a fố gondot, hanem az, hogy míg a fejlett európai országokban a vállalati $\mathrm{K}+\mathrm{F}$ helyek részesedése $54,8 \%$ (Ausztria) és $77,7 \%$ (Svájc) között szóródik, addig Magyarországon csupán 33,3\%. A sokak által hangoztatott akadémiai-egyetemi fúzió tehát csak a gondok elkendôzését jelentené, ez a megoldás hamis illúzió a kutatásfinanszírozás gyökeres reformja és stratégiai pozícióinak a költségvetésben való érvényesítése helyett.

2) Az egyetemi - ipari kapcsolatok - a university-industry linkage rendszerek - intézményesitésének, finanszírozásának ma még nincsenek általánosan használható modelljei, formái, a két szféra közötti együttmứködés esetleges, a kooperációk is többnyire az egyetemek anyagi kondícióinak a javítását, mintsem az innovációs lánc kiépülését szolgálják.

A felsóoktatás szerkezete tradicionális, az elkülönült diszciplínák szerint tagolodó intézményrendszer integrálása felesleges energiákat emészt fel, ahelyett, hogy a tudományszervezés középpontjában a $\mathrm{K}+\mathrm{F}$ és a gazdaság együttmüködése állna. A regionális fejlôdés akadályának tekinthetô, hogy Magyarországon a délnyugati-északkeleti ,,energiatengely' alatt, a Dél-Dunántúlon és az Alföldön nincs jelentôs mûszaki felsôoktatási intézmény.

A felsóoktatás területi struktúrája ambivalens vonásokat mutat: regionális eloszlása szélsôségesen diszperz, a legnagyobb vidéki egyetemek sem felelnek meg a nemzetközi normáknak. A 33 településen müködõ, átlagos hallgatói létszámában - és az ezzel szoros kapcsolatot mutató kutatási kapacitásában - az európai átlag ötödrészét sem elérõ intézmények képtelenek az európai $K+F$ versenykövetelményeknek megfelelni. Nincs egyetlen vidéki egyetem sem, amelyiknek kari-diszciplináris tagolódása megfelelne az EU felsốoktatás-fejlesztési stratégiájának. Csupán egyetlen vidéki egyetemen folyik például magasszintü marketingképzés, s egyetlen vidéki felsôoktatási intézményben sincs formatervezôi, alkalmazott iparmũvész képzés.

A felsorolt hiányosságokból érzékelhetô, hogy az innovációs rendszernek ebben a szegmensében a változásokat, a feladatok súlya és a nemzetközi normák érvényesítése miatt, országos politikai döntéseknek kell elindítaniuk. 


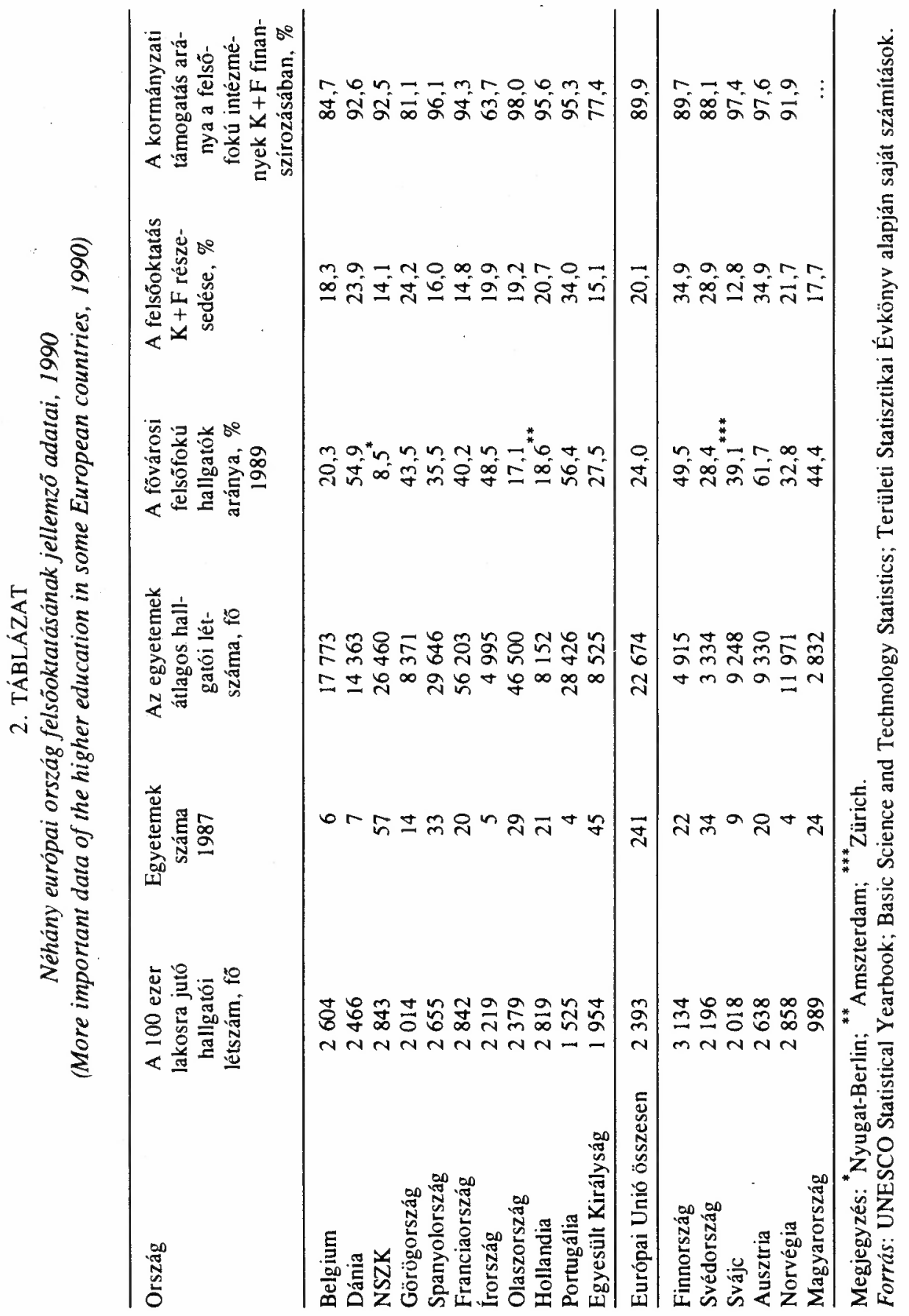


A regionális politikai kormányzati szerveknek egyrészt bizonyitaniuk kell a felsõoktatás és a regionális fejlôdés szoros kölcsönhatását, másrészt fel kell hívniuk a figyelmet arra, hogy a magyar felsôoktatás hosszú távú fejlesztési programja nem szolgálja a technológiaváltás és a gazdasági modernizáció regionális feltételrendszerének a megteremtését. A ,,Felsổoktatás 2000" program ugyanis elsôsorban a jelenlegi szerkezet mennyiségi változásait extrapolálta és nem volt tekintettel az elốbb említett innovációintegráló funkciók kiépítésének igényére.

A Dél-Dunántúl felsôoktatásának hagyományos vonásokat tükrözổ szerkezete csak abban az esetben változhat, ha a megfelelố felsổoktatás-politikai döntések megszületnek. (A régió felsõoktatási hálózatára a vidéki intézményrendszer elôbb említett negatív vonásai a jellemzốek.)

A Dél-Dunántúl tíz felsôoktatási intézményében Keszthelyen, Zalaegerszegen, Kaposvárott, Szekszárdon és Pécsett közel 10,5 ezer hallgató tanult 1992-ben, az ország összes felsôoktatási hallgatóinak 9,0\%-a (3. táblázat).

\section{TÁBLÁZAT}

A magyar felsôfokú hallgatói létszám területi tagozódása, 1992

(Regional division of the number of students of higher education in Hungary, 1992)

\begin{tabular}{lcc}
\hline Régió & $\begin{array}{c}\text { Hallgatói } \\
\text { létszam, fố }\end{array}$ & $\begin{array}{c}\text { Megoszlás, } \\
\%\end{array}$ \\
\hline Észak-Dunántúl & 12911 & 11,0 \\
Észak-Magyarország & 9888 & 8,4 \\
Észak-Alföld & 13312 & 11,4 \\
Dél-Alföld & 15221 & 13,0 \\
Központi & 55239 & 47,2 \\
Dél-Dunántúl & 10579 & 9,0 \\
\hline Összesen & 117150 & 100,0 \\
\hline
\end{tabular}

Forrás: Területi Statisztikai Évkönyv alapján saját számítások.

A 80-as évtized a stagnálás korszaka volt a magyar felsổoktatásban. 1980-1992 között a hallgatói létszám mindössze 15,8\%-kal nốtt. A Dél-Dunántúlon viszont 2,4\%-os volt a növekedés, annak ellenére, hogy a szekszárdi tanitóképzố fejlesztése erre az idốszakra esett. A levelezô képzés visszaszorulása miatt visszaesés volt tapasztalható Pécsett $(15,3 \%)$ és Kaposvárott $(6,5 \%)$.

E változások üteme és mértéke - illetve a századfordulóig szóló kormányzati felsốoktatás-fejlesztési elképzelések - azonban nem azt jelzik, hogy dinamikus fejlôdési szakasz venné kezdetét. A kormányzati prognózisok 2000-ben is csupán 14 ezer hallgatóval számolnak. Ez pedig egyértelmúen a jelenlegi kedvezốtlen állapot konzerválását jelenti. 1992-ben ugyanis Magyarországon a százezer lakosra jutó hallgatói létszám 1136 fổ (a közös piaci átlag 47,5\%-a). A Dél-Dunántúlon ez a mutató 807 fố, 
a központi régióban 1862 fô, az Alföldön 978 fô,, az Észak-Dunántúlon 712 fô, ÉszakMagyarországon pedig 759 fổ. Bár hazai összehasonlításban a Dél-Dunántúl nincs a legkedvezôtlenebb helyzetben, a nemzetközi összevetés azonban már egyértelmũen az elmaradottságot bizonyítja (4. ábra). Ha a kormányzati prognózist nézzük, e mutató feltételezve, hogy a népesség nem változik - 1076 fổ lesz, amiáltal a Dél-Dunántúl továbbra is a közép-európai régiók utolsó harmadában helyezkedik majd el.

A régió felsõoktatási hálózatának diszciplináris tagolódása sem felel meg a dinamikus gazdaságfejlesztés követelményeinek. A képzési struktúra konzervatív, a korábbi fejlôdési pálya hatása még erõteljesen érzõdik a szakmai szerkezeten. A piacosodó gazdaság, az exportorientált termelés- és szolgáltatásfejlesztés, a technológiai váltás szakemberszükséglete ebben a struktúrában nem elégíthetô ki (5. ábra).

\section{A fejletlen termelö és üzleti szolgáltatások}

A fejlett európai piacgazdaságok elmúlt két évtizedbeli átalakulásának egyik leglátványosabb kísérô jelensége a tercier szektor mennyiségi megerốsödése és minốségi differenciálódása volt. E szektor az Európai Unió minden országában a foglalkoztatotti struktúrában domináns pozícióba került. Az európai régiók szerkezeti átalakulásának is egyik fontos eredménye a szolgáltatási ágazatok részesedésének növekedése: a prosperáló, a foglalkoztatotti létszámot folyamatosan bốvítô régiókban arányuk ma már meghaladja az 50\%-ot. Az Európai Unió regionális kategóriáit alkalmazva a 4. táblázat néhány közép-európai régió tercier ágazatának részesedését mutatja. (A besorolás a nem közös piaci régiók esetében természetesen esetleges, az adatokból azonban egyértelmũ a következtetés: a környezõ térségek a tercierizálódás magasabb fokán állnak.)

Míg a foglalkoztatás bõvítése szempontjából a tercier ágazatnak általában meghatározó a szerepe, a gazdasági teljesító- és versenyképességet a szolgáltatások speciális fajtái, az ún. termelô és üzleti szolgáltatások befolyásolják. Ebbe a csoportba tartozik a már elemzett kutatás-fejlesztés, és ide sorolhatók még mindazok a tevékenységek, amelyek az innovációs lánc (1.ábra) utolsó blokkját alkotják. Ennek a szolgáltatásfajtának a jelentốsége több ok miatt nôtt meg az utóbbi két évtizedben. E tényezôket azért is érdemes lesz majd alaposabban megvizsgálni, mert perspektivikus szerepükre várhatóan a Dél-Dunántúlon is számítani kell. 


\section{4. ÁBRA}

A százezer lakosra jutó hallgatói létszám néhány közép-európai régióban, 1992 (The number of students per one hundred thousands inhabitants in some Central European regions, 1992)

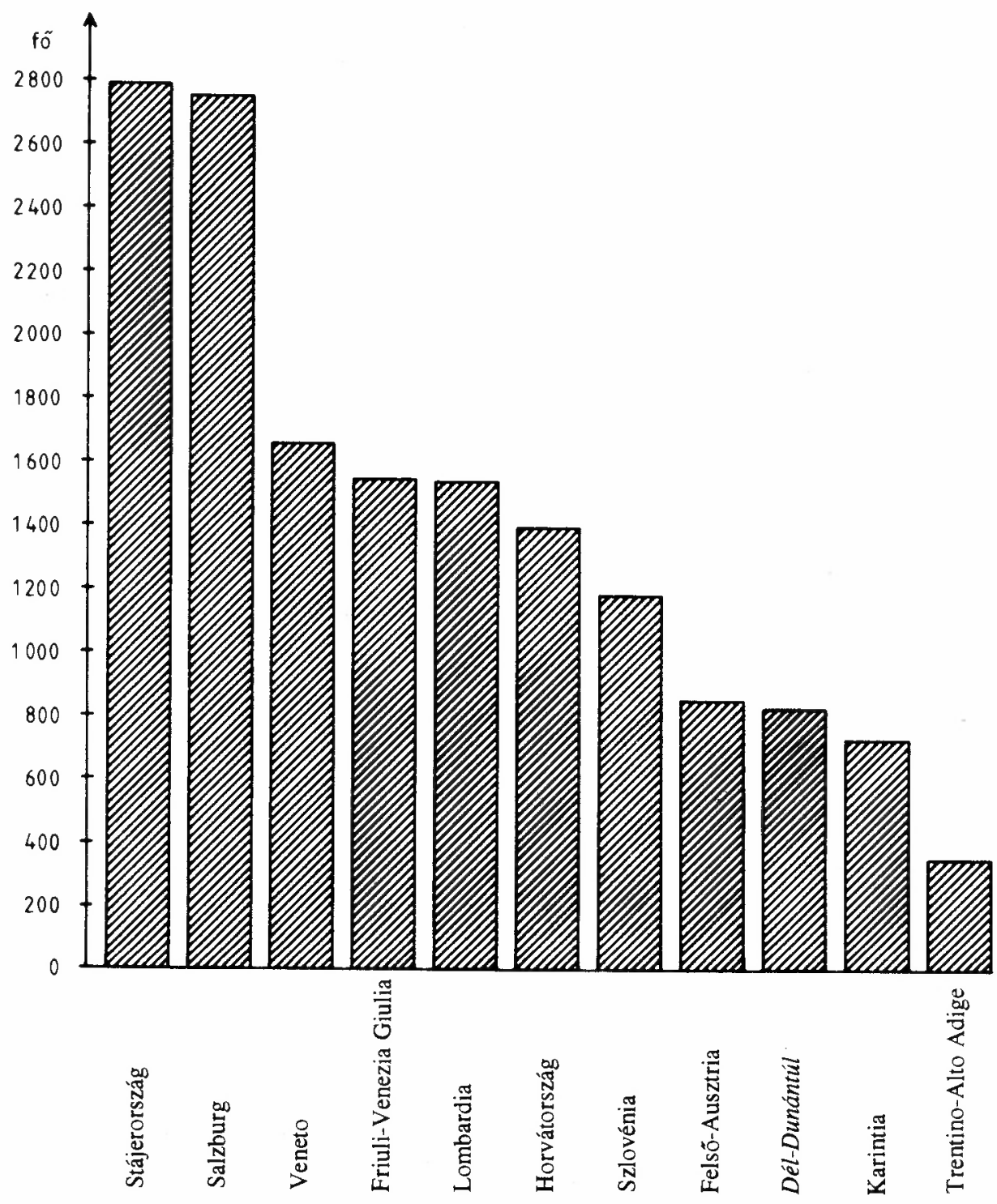

Szerkesztette: Horváth Gyula. 


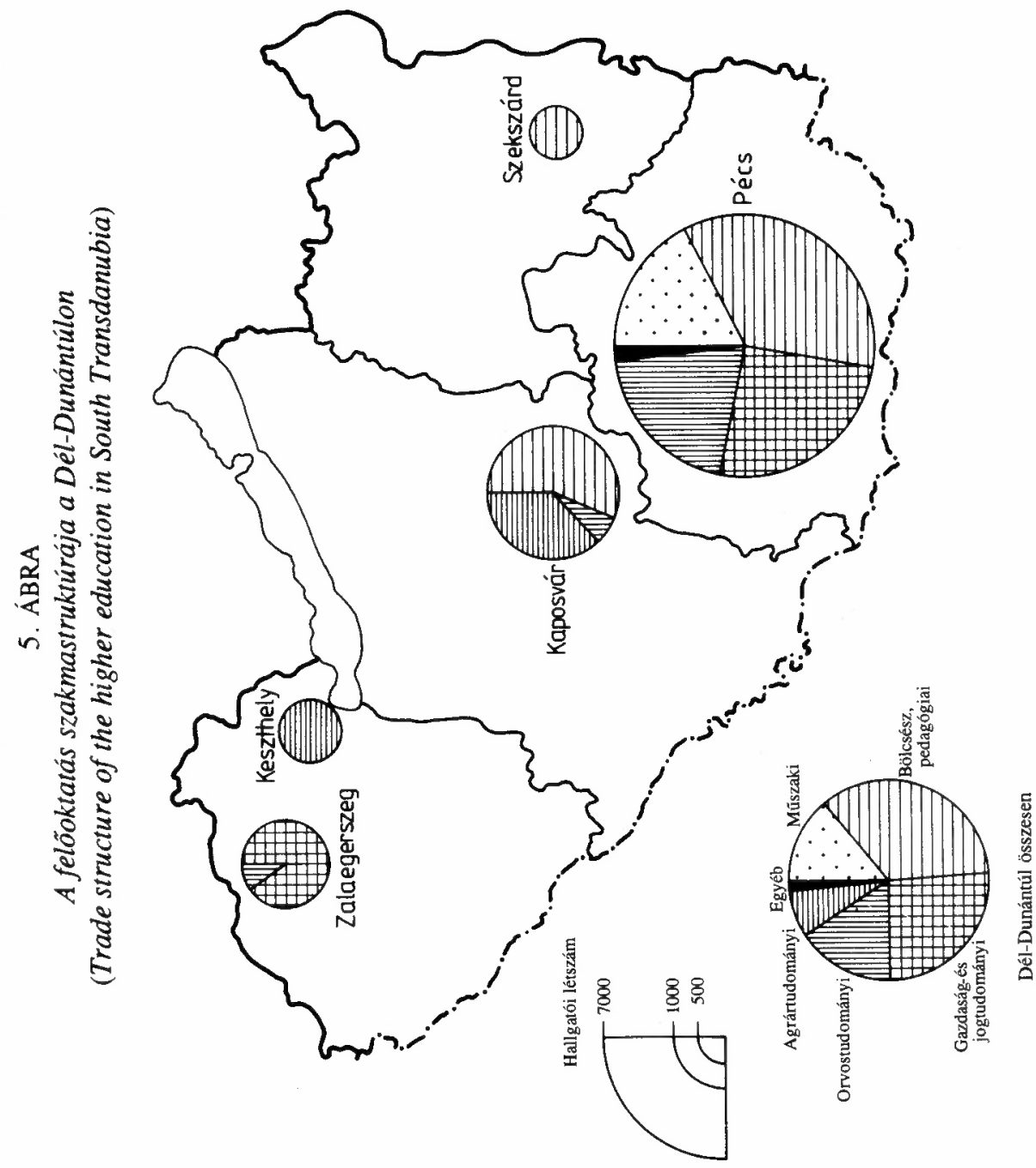




\section{TÁBLÁZAT}

A tercier szektor aránya az összes foglalkoztatottból

néhány közép-európai régióban, 1988

(The rate of tertiary sector from all employees in some

Central European regions, 1988)

\begin{tabular}{|c|c|c|}
\hline Régiótípus & Régió & $\begin{array}{l}\text { A tercier foglalkoz- } \\
\text { tatottak aránya, \% }\end{array}$ \\
\hline Elmaradott régió & $\begin{array}{l}\text { Karintia (AU) } \\
\text { Burgenland (AU) } \\
\text { Trentino-Alto Adige (I) } \\
\text { Szlovénia } \\
\text { Horvátország }\end{array}$ & $\begin{array}{l}52,6 \\
52,8 \\
64,8^{*} \\
48,5 \\
45,3\end{array}$ \\
\hline $\begin{array}{l}\text { Depressziós - hanyatló } \\
\text { iparral rendelkezô régió }\end{array}$ & $\begin{array}{l}\text { Felsõ-Ausztria (AU) } \\
\text { Liguria (I) } \\
\text { Piemonte (I) }\end{array}$ & $\begin{array}{l}41,8 \\
72,4 \\
51,9 \\
\end{array}$ \\
\hline Dinamikusan fejlődổ régió & $\begin{array}{l}\text { Bajorország (D) } \\
\text { Baden-Württemberg (D) } \\
\text { Lombardia (I) } \\
\text { Veneto (I) } \\
\text { Friuli-Venezia Giulia (I) } \\
\text { Stájerország (AU) } \\
\text { Salzburg (AU) }\end{array}$ & $\begin{array}{l}53,1 \\
47,9^{*} \\
53,6^{*} \\
51,7^{*} \\
63,2^{*} \\
42,2 \\
57,9\end{array}$ \\
\hline Dél-Dunántúl ${ }^{* *}$ & $\begin{array}{l}\text { Baranya } \\
\text { Somogy } \\
\text { Tolna } \\
\text { Zala } \\
\end{array}$ & $\begin{array}{l}45,9 \\
48,9 \\
40,2 \\
43,7\end{array}$ \\
\hline Dél-Dunántúl & Összesen & 45,2 \\
\hline Magyarország ${ }^{* *}$ & Összesen & 46,5 \\
\hline
\end{tabular}

*1991; ${ }^{* *} 1990$. Forrás: Horváth Gy. 1993a, 1993 b.

1) A gazdasági versenyben nốtt az innovációs és a nem árjellegũ faktorok befolyása, a szabványosított tömegtermékek aránya csökken, a termék- és piaci diverzifikáció fokozódik. Ez a változás a termelés és a szolgáltatások kooperációjának az erõsítését indukálja, hiszen szû́kebb fogyasztói csoportok különleges igényeit kell kielégíteni.

2) Az információ és a piaci-múszaki ismeretek szerepe megnõtt, a technológiai és a termékváltás nyomán az elsôdleges nyersanyagokat és a manuális megmunkálást felülmúló termelési inputtá váltak.

3) A vállalati döntési folyamatok komplexitása a helyi-regionális clusterek kialakításával erôsödött, a lokális kooperáció összetett irányítási feladatokat eredményezett.

4) A gyors technológiai változások miatt a döntési folyamatok időhorizontja tágult a gazdaság jobb tervezhetôsége érdekében. 
5) A szállítás és a kommunikáció rohamos fejlődése a termelés-értékesítés reakcióidejét csökkentette, ami új speciális feladatokat generált.

6) A vállalatok múködését befolyásoló externalitások (közös piaci szabványok, minôségi normák, kötelezô elôírások stb.) szerepe fokozódott.

Ebben az ûj ipari fejlôdési szakaszban - a Dél-Dunántúl az e fejlődési fázisba lépett közép-európai régiók peremén helyezkedik el - a vállalkozások számára tehát nem elsôsorban az anyagi jellegú input-output kapcsolatok, hanem az új technológiai elônyöket hasznosítani képes, a piaci fejlôdést ösztönzõ technológiai, információs és pénzügyi erōforrások válnak meghatározó tényezôvé. Ezeknek az erôforrásoknak a feltárásában, összehangolásában van kitüntetett szerepük a termelô és üzleti szolgáltatásoknak.

E szolgáltatások fejlettsége határozza meg lényegében egy régió belsố fejlôdôképességét, azt nevezetesen, hogy ezeket az újfajta gazdasági hajtóerốket a régió milyen szervezeti hálózatokkal képes önmaga - saját szükségleteinek optimális kielégítése érdekében - hasznosítani. Amennyiben ilyen szervezetekkel nem vagy csak részlegesen rendelkezik, gazdaságának másutt - a centrumrégiókban - kell e szolgáltatásokat igénybe vennie, ami viszont a gazdasági függés egy új - következményeit tekintve azonban a dezindusztrializáció negatívumaihoz hasonlóan hátrányos - válfaját alakítja ki. Ezért van nagy jelentôsége annak, hogy a regionális politika ösztönzókkel segítse $e$ szolgáltatások elterjedését.

A Dél-Dunántúlon - mint ahogy a vidéki Magyarországon általában - a termeló és üzleti szolgáltatásoknak mind a kínálati skálája, mind pedig minôsége nagyon gyenge. A szervezetek száma is elenyészõ, alacsony továbbá az ágazatcsoportban foglalkoztatottak aránya (5. táblázat).

\section{TÁBLÁZAT}

Az üzleti és termeló szolgáltatások foglalkoztatottainak száma, 1990 (fó)

(Number of business and productive service employees, 1990 [persons])

\begin{tabular}{lccccc}
\hline Megye & $\begin{array}{c}\text { Banki, } \\
\text { pénzügyi, } \\
\text { biztosítási } \\
\text { szolgáltatás }\end{array}$ & $\mathrm{K}+\mathrm{F}^{*}$ & $\begin{array}{c}\text { Üzleti } \\
\text { szolgálta- } \\
\text { tások }\end{array}$ & Összesen & $\begin{array}{c}\text { Az összes } \\
\text { foglalkoz- } \\
\text { tatott } \\
\% \text {-ában }\end{array}$ \\
\hline Baranya & 1668 & 230 & 936 & 2834 & 1,6 \\
Somogy & 1511 & 85 & 576 & 2172 & 1,5 \\
Tolna & 1063 & 152 & 418 & 1633 & 1,5 \\
Zala & 1147 & 153 & 440 & 1735 & 1,3 \\
\hline Dél-Dunántúl & 5389 & 620 & 2370 & 837.4 & 1,5 \\
\hline Dél-Dunántúl az & 11,8 & 3,5 & 5,7 & & 7,6 \\
ország \%-ában & & & & & $\ldots$ \\
\hline
\end{tabular}

*Teljes munkaidejũ dolgozókra átszámított létszám.

Forrás: 1990. évi népszámlálás. Megyei kötetek. 
E tevékenységek a fejlett országokban városi települtségüek, a Dél-Dunántúl esetében is ez a jellemzõ. Az öt meghatározó város ellátottsági helyzetét illusztráljuk a 6. ábrán, meglehetôsen becsült adatok alapján. Mind a minôsítési kategóriák, mind pedig a városok pozíciójának a meghatározása hipotetikus, inkább azt kívántuk érzékeltetni, hogy melyek lehetnek a piacgazdaság szempontjából kívánatos tevékenységfajták és melyek hiányoznak teljes mértékben a térségben, illetôleg megítélésünk szerint melyek a legfejletlenebb formák.

\section{6. ÁBRA}

A fejlett szolgáltatásokkal való ellátottság jellemzổ a Dél-Dunántúlon, 1993

(Provision with developed services in South Transdanubia, 1993)

\begin{tabular}{|c|c|c|c|c|c|c|}
\hline & & $\begin{array}{l}\text { Pécs } \\
2.3 .\end{array}$ & $\begin{array}{l}\text { Kaposvár } \\
\text { 1. 2. } 3 .\end{array}$ & $\begin{array}{l}\text { Szekszárd } \\
\text { 1. 2. } 3 .\end{array}$ & $\begin{array}{c}\text { Zalaegerszeg } \\
\text { 1. 2. } 3 .\end{array}$ & $\begin{array}{c}\text { Nagykanizsa } \\
\text { 1. } 2.3 .\end{array}$ \\
\hline $\begin{array}{l}\text { Ipari és vegyipari } \\
\text { termékelemzés }\end{array}$ & . & & = & - & = & $\mathbf{n}$ \\
\hline Minōségellenôrzés & e & & $\mathbf{n}$ & • & - & 0 \\
\hline Védjegyszolgáltaltás & 0 & & 0 & 0 & 0 & 0 \\
\hline Ipari consulting & a & & - & - & - & $=$ \\
\hline Design & 0 & & 0 & 0 & 0 & 0 \\
\hline Mérnöki szolgáltatás & & n & a & a & - & a \\
\hline $\begin{array}{l}\text { K+F szolgáltatás } \\
\text { Pályaválasztási }\end{array}$ & 0 & & 0 & 0 & 0 & 0 \\
\hline tanácsadás & & • & $\mathbf{v}$ & - & - & $\mathbf{n}$ \\
\hline $\begin{array}{l}\text { Személyzeti } \\
\text { tanácsadás }\end{array}$ & & = & - & - & E & घ \\
\hline $\begin{array}{l}\text { Tôzsdetanácsadás } \\
\text { Könyvelés }\end{array}$ & 0 & m & 0 & 0 & o & O \\
\hline $\begin{array}{l}\text { Biztosítási } \\
\text { consulting }\end{array}$ & & ט & E & घ & e & E \\
\hline Pénzügyi tanácsadás & घ & & - & घ & E & - \\
\hline Hiteltanácsadás & $\mathbf{0}$ & & $=$ & - & $\mathbf{-}$ & $\mathbf{n}$ \\
\hline Lízing & - & & a & $\mathbf{E}$ & घ & - \\
\hline Banki szoltáltalgás & & e & ! & - & a & $\boldsymbol{\theta}$ \\
\hline $\begin{array}{l}\text { Beruházási tanácsadás } \\
\text { Factoring }\end{array}$ & 0 & $\mathbf{m}$ & O & a & $\stackrel{0}{a}$ & : \\
\hline Részvényközvetítés & 0 & & 0 & 0 & 0 & 0 \\
\hline Marketing, piackutatás & & - & 0 & 0 & 0 & 0 \\
\hline Publions relations & 0 & & 0 & 0 & 0 & 0 \\
\hline Hirdetés & & - & - & - & $\mathbf{m}$ & a \\
\hline $\begin{array}{l}\text { Fordítás, tolmácsolás } \\
\text { Kongresszus- és }\end{array}$ & & - & - & - & a & - \\
\hline konferenciaszervezés & - & & E & 0 & 0 & 0 \\
\hline $\begin{array}{l}\text { Kiállítás- és } \\
\text { vásárszervezés }\end{array}$ & & - & E & $=$ & - & - \\
\hline $\begin{array}{l}\text { Kiállitás- és } \\
\text { vásár berendezés }\end{array}$ & & - & 0 & 0 & 0 & 0 \\
\hline
\end{tabular}

1 - fejletlen, 2 - közepesen fejlett, 3 - fejlett. 
A megyeszékhelyek viszonylag kedvezőbb helyzetben azokban a szolgáltatásfajtákban vannak, amelyek hagyományosan megyei szervezettségũek (biztosítás, pályaválasztási tanácsadás, hirdetés, minôségellenôrzés) vagy pedig, amelyek vonatkozásában az új , „elephelyes” szervezetek (személyzeti tanácsadás, banki szolgáltatások) értelemszerũen a legnagyobb várost választották.

A kis- és középvállalkozások legalapvetôbb funkcióját kielégítõ szolgáltatás (könyvelés) terén minősíthetõ a kép kedvezõnek, a többi szolgáltatásfajta jelenléte a régió nagyobb városaiban is szerény; a jelenlegi ellátottsági színvonal miatt a régió innovációs képességének fejlödése elött komoly akadályok állnak (6. ábra).

\section{Összegzés}

A Dél-Dunántúl gazdaságának fejlettségi színvonalára a gazdaság szerkezetén, üzemi struktúráján és az irányítási-alárendeltségi szervezeti viszonyokon kívül a régió innovációs potenciálja, a termelés-elosztás-értékesítés technológiai állapota és minõsége is hatással volt. A viszonylag késõn lezajlott iparosítás a térség erõteljes külsõ függését eredményezte. A vállalati struktúrák és tulajdonviszonyok átalakulását követōen a belsõ gazdasági szereplök száma ugyan megnôtt, a termelés- és termékfejlesztés - hagyományok híján - azonban alacsony színvonalú, a gazdaság új szereplõi többnyire ,,jogelódjeik" termelési kultúráját folytatják. A termék- és technológiaváltás feltételei a régióban kedvezõtlenek, az elmúlt két-három évben tapasztalt változások arra figyelmeztetnek, hogy fennáll a veszélye annak, hogy újfajta függõség alakul ki a fốváros és a régió között: a ,,szúrō' modell tovább mũködik, a központi régió - lokalizációs elõnyeit kihasználva - megszũri a legértékesebb termelési tevékenységeket - a kutatás-fejlesztést, a pénzügyi szolgáltatásokat, a felsõoktatást, a nemzetközi piaci kapcsolatépítõ tevékenységet stb. - és a perifériákra irányítja a hagyományos, kevésbé jövedelmezõ termelési ágakat. A dél-dunántúli gazdaság számára - bár jelenthet rövid távú elõnyöket az elmaradott térségek fejlesztésében - ez a megoldás nem lehet stratégiai irányvonal, mert egyértelmúen a régió erõsen periférikus vonásokat hordozó szerkezetét konzerválná (7. ábra). A Dél-Dunántúl csak gazdasági autonómiájának erõsítésével lesz képes szerkezetének modernizálására, a foglalkoztatottak számának emelésére, jövedelmi kondícióinak javítására.

Az innovációs potenciál - statisztikai adatokkal már ma is értékelhetô - elemeit vizsgálva, a kirajzolódó kedvezôtlen helyzetkép miatt megállapíthatjuk, hogy a régió fejlesztési stratégiájában a termék- és technológiai fejlesztés valamennyị tényezõjének és az ezek közötti kapcsolatok kialakításában érvényesíteni kell a fejlett piacgazdaságok tapasztalatait. Meg kell fogalmazni a $\mathrm{K}+\mathrm{F}$, a technológiai transzferrendszerek fejlesztésének lehetôségeit, javaslatokat kell tenni a magyar technológiapolitika regionális támogatási rendszerének kidolgozására, és körül kell határolni a belsõ regionális ösztönzések formáit. 

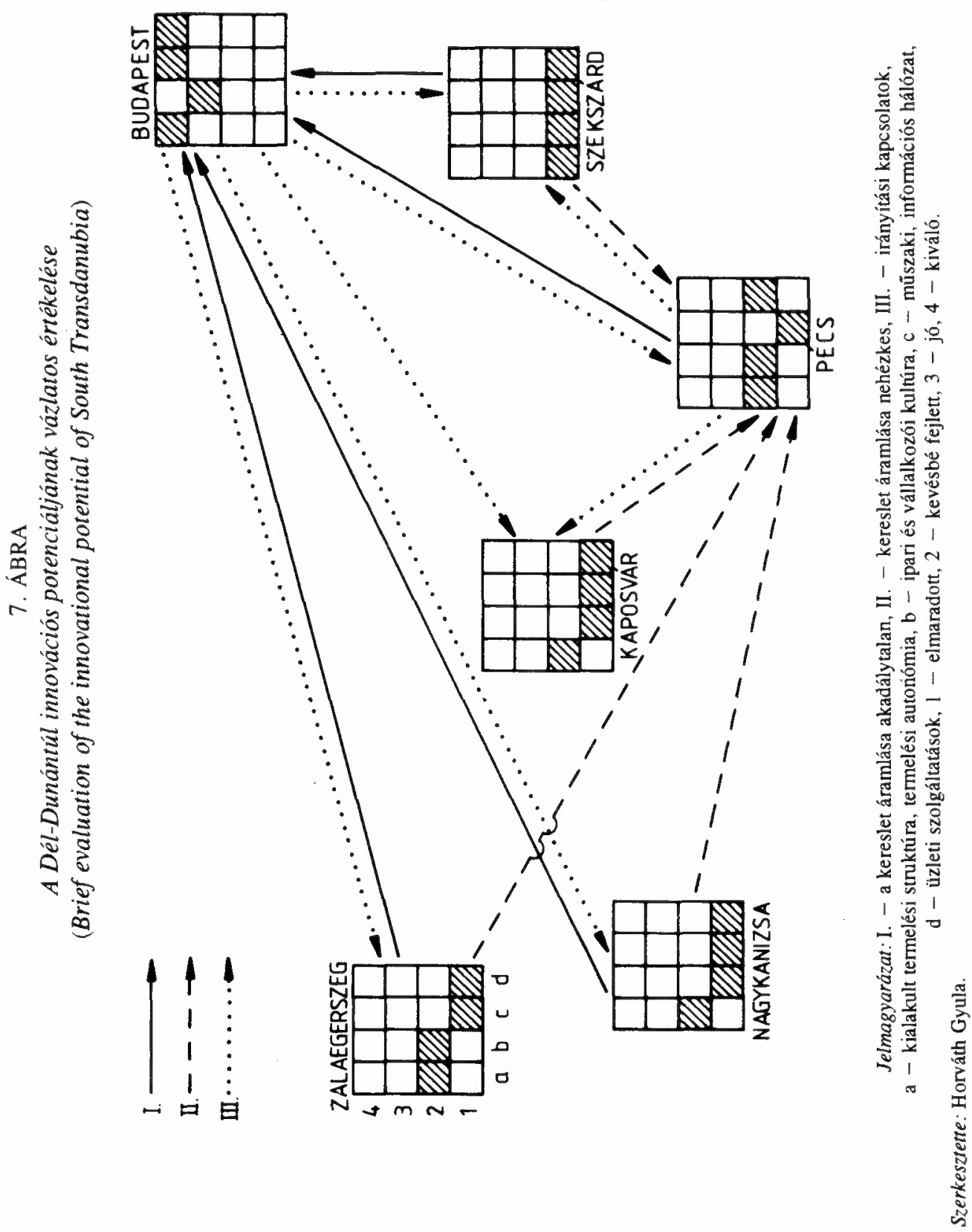


\section{Irodalom}

Amstrong, H. - Taylor, J. (1993) Regional Economics and Policy. Harvester Wheatsheaf, London.

Basic Science and Technology Statistics. OECD, 1991. Paris.

Benko, G.-Dunford, M. (eds.) (1991) Industrial Change and Regional Development. Belhaven Press, London.

Bennett, R. J. - Krebs, G. (eds.) (1991) Local Economic Development: Public-private Partnership Initiatives in Britain and Germany. Belhaven Press, London.

Ciciotti, E. (1993) Competitività e territorio. L'economia regionale nei paesi industrializzati. La Nuova Italia Scientifica, Roma.

Enyedi Gy. (szerk.) (1993) Társadalmi-területi egyenlötlenségek Magyarországon. Közgazdasági és Jogi Könyvkiadó, Budapest.

European Regional Prospects. An Analysis and Forecasts to 1995. Cambridge Econometrics, 1991. Cambridge.

Felsôoktatás 2000. Mũvelódési és Közoktatási Minisztérium. 1993. Budapest.

Horváth Gy. (1981) A területi-közigazgatási egységek gazdasági kapcsolatainak vizsgálata. MTA Dunántúli Tudományos Intézete, Közlemények, 28. Pécs, 65-92. o.

Horváth Gy. (szerk.) (1993a) Régiók és városok az olasz modernizációban. MTA Regionális Kutatások Központja, Pécs.

Horváth Gy. (ed.) (1993b) Development Strategies in the Alpine-Adriatic Region. HAS, Centre for Regional Studies, Pécs.

Kraftné Somogyi G. (ed.) (1993) Small and Medium Sized Enterprises and Regional Development. Centre for Regional Studies, Pécs.

Malecki, E. J. (1990) Technological innovation and path to regional economic growth. In: Growth Policy in An Age of High Technology. (Schmandt, J., Wilson, R. W. eds.) Unwin Hyman, London, 246-268. o.

Malecki, E. J. (1991) Technology and Economic Development. Longman, Harlow.

Quince, R. (1993) European Community Strategic Programme for Innovation and Technology Transfer (Sprint): Mid-term review. Commission of the European Communities, Brussels.

Rechnitzer J. (1993) Szétszakadás vagy felzárkózás. A térszerkezetet alakító innovációk. MTA Regionális Kutatások Központja, Gyốr.

Statistical Yearbook. UNESCO, 1991. Paris.

STRIDE: Science and Technology for Regional Innovation and Development in Europe. Commission of the European Communities, 1988. Brussels.

Területi Statisztikai Évkönyv 1992. KSH, Budapest, 1993.

Tudományos kutatás és fejlesztés 1986. KSH, Budapest, 1988. 


\section{PREREQUISITE OF THE INTERNATIONAL COMPETITIVENESS OF SOUTH TRANSDANUBIA: TECHNOLOGICAL RENEWAL}

\section{GYULA HORVÁTH}

The development level of the South Transdanubian economy was affected by besides the economic structure, company structure, control-subordinate organisational relationships - the innovative potential of the region, the technological state and quality of the production-distribution-selling process. The industrialisation that had taken place relatively late amounted to the dependant status of the region on outside factors. Although, following the transition of company structures and ownership patterns the number of inner economic actors increased, the production- and product development - due to the lack of traditions - still has a low level, the new economic actors usually follow the productive culture of their "predecessors". The conditions of the change of products and technology in the region are unfavourable. The changes experienced in the past three or four years show the danger of the formation of a newtype dependence between the capital and the region: the "filter" model still functions, the central region - using its localisational advantages - filters the most precious productive activities - research and development, financial services, higher education, building international markets etc. - and diverts the traditional, less profitable productive branches to the peripheries.

For the economy of South Transdanubia - although it might mean short-term advantages in the development of the backward regions - this solution cannot be a strategic trend, since it would inevitably preserve the structure of the region that already shows strong peripheral features. South Transdanubia will be able to modernise its structure, increase the number of the employed and improve their incomes through the strengthening of its economic autonomy, only.

Seeing the unfavourable picture of the innovation potential we can state that in the development strategy of the region the experience of the developed countries have to be utilised in the formation of all the factors of product- and technological development and also of the relationships of these factors.

The author claims the opportunities of $R \& D$, the development of technological transfer-systems. He also makes a suggestion for the development of the regional support system of the Hungarian technological policy and he defines the forms of the inner regional incentives. 